\title{
Unusual Relationship between the Piriform Muscle and Sciatic, Inferior Gluteal and Posterior Femoral Cutaneous Nerves
}

\author{
Relación Inusual entre el Músculo Piriforme y los Nervios \\ Isquiático, Glúteo Inferior y Cutâneo Femoral Posterior
}

Jacomo, A. L."; Martinez, C. A. R.*; Saleh, S. O."; Andrade, M." \& Akamatsu, F. E..

JACOMO, A. L.; MARTinez, C. A. R.; SALEH, S. O.; ANDRADE, M. \& AKAMATSU, F. E. Unusual relationship between the piriform muscle and sciatic, inferior gluteal and posterior femoral cutaneous nerves. Int. J. Morphol., 32(2):432-434, 2014.

SUMMARY: Piriformis muscle syndrome has been increasingly recognized as a cause of leg pain. Overuse, strain, or anatomical variations of the relationship between the nerve and the piriformis muscle are thought to be the underlying causes of the entrapment of the sciatic nerve. We report a variation not previously described which was found during a routine dissection. During routine dissection of the left gluteal region of an adult male cadaver we observed a high division of the sciatic nerve and the presence of an accessory piriformis muscle. The sciatic nerve divided beneath the piriformis muscle and the common fibular nerve passed over the accessory piriformis muscle, whereas the tibial nerve reflected anteriorly to pass between the accessory piriformis and the superior gemellus muscle. Additionally, both nerves communicated with a side branch under the inferior border of the accessory piriformis muscle and the inferior gluteal nerve originated from the fibular nerve. Anatomical variations in the relationship between the piriformis muscle and the sciatic nerve may be present in up to $17 \%$ of the population. Six different variations have been described and none of them is similar to our description. Though complete understanding of the physiopathology of the piriformis muscle syndrome remains to be elucidated, knowledge of the possible anatomical variations may be useful for its adequate diagnosis and treatment.

KEY WORDS: Inferior gluteal nerve; Sciatic nerve; Piriformis muscle.

\section{INTRODUCTION}

Anatomical variations between the piriform muscle and sciatic nerve and its consequences in clinical practice have been described by several authors (Cassidy et al., 2012; Smoll, 2010; Güvencer et al., 2008; Papadopoulos \& Khan, 2004; Benzon et al., 2003). Anatomic variations between the piriform muscle and the inferior gluteal nerve has also been described by some authors (Mandiola et al., 1986; Gabrielli et al., 1997). These anatomical descriptions provide accurate information on the morphology and the topographic relationships between these structures, very significant because these descriptions are of great importance for clinical practice. Thus, in this case report, an anatomical variation not yet found in the literature is described equally in relation to nerves and to the piriform muscle.

\section{CASE REPORT}

During routine dissection in the Anatomy Laboratory of the Department of Human Structural Topography, Medical
School, Universidade de São Paulo (USP) a 58-year-old Caucasian male cadaver, weighing $70 \mathrm{~kg}, 1.70 \mathrm{~cm}$ height, was found with an unusual anatomical variation. No information of muscular or neurological disease was found in his medical history. On inspection no signs of previous surgery, muscle lesion or atrophy in the lower limb were found.

The dissection proceeded as follows: cadaver was positioned in the ventral decubitus position. The skin of gluteal region, the subcutaneous tissue and the gluteus maximums muscle were pulled apart by a longitudinal incision on the lateral portion, leaving these structures medially fixed. The vascular and nervous pedicle was dissected carefully in order to preserve sciatic, posterior femoral cutaneous and inferior gluteal nerves. These findings were recorded by a Nikon D40 camera.

Initially, the sciatic, posterior femoral cutaneous and inferior gluteal nerves were found emerging from the bottom edge of the piriform muscle. However, it was observed that in this region, the gluteal inferior nerve received a branch

\footnotetext{
* Laboratory of Medical Research (LIM 02), Department of Surgery, Medical School, University of São Paulo, São Paulo, Brazil.

** Universidade São Francisco, Bragança Paulista, SP, Brazil,
} 
originating from the lateral portion of the sciatic nerve (common peroneal). Therefore, it was decided to expand the dissection, and piriform muscle at its origin was dissected and it was possible to observe the following: 1 . In the depth of the piriform muscle, an accessory piriform muscle was found; 2 . This deep accessory piriform muscle showed on its superficial face, the common peroneal and the inferior gluteal nerve simply emerging from this peroneal branch, both emerging from the top edge of this muscle; 3 . Also, the tibial branch and posterior femoral cutaneous nerve emerged from the bottom of the deep accessory piriform muscle (Fig. 1).

\section{DISCUSSION}

The knowledge of anatomical variations is particularly important in clinical practice, especially in radiological diagnoses and surgical procedures. This case report shows an anatomical variation of the piriform muscle and its relationship to the sciatic, inferior gluteal and posterior femoral cutaneous nerves. Beaton \& Anson (1937) in a study with 6,000 cadavers described 6 types of anatomic relationship between the sciatic nerve and piriform muscle, but none of these types was similar to our findings. Smoll showed that in $7 \%$ of cases, the sciatic nerve was divided into a branch perforating the piriform muscle and, other passing inferior to the piriform muscle. Jawish et al. (2010) showed the frequency of these six kinds of anatomical relationship. Cassidy et al., described a variation where the sciatic nerve emerged from the bottom edge of the piriform muscle, however, an accessory piriform muscle located inferior to that muscle passed between the tibial and common peroneal portion of the sciatic nerve. The findings of this study are different from those found by Cassidy et al., because the common peroneal portion and inferior gluteal nerve emerged from the top edge of this deep accessory muscle, whereas the tibial and posterior femoral of the thigh emerged from the bottom edge of this piriform muscle. Our study is partly in accordance with Gabrielli et al., in that a high division of the sciatic nerve may lead the inferior gluteal nerve to have the same path dividing the common peroneal; in our findings, the inferior gluteal nerve emerged together with the common peroneal branch in the upper border of the deep accessory piriform muscle. Anatomic variations in muscles and nerves with abnormal origin, course and distribution may explain muscle pain (myalgia), and neuropathies. Thus, it is of great clinical importance the knowledge of possible anatomic variations that may affect the gluteal region.

JACOMO, A.L.; MARTINEZ, C.A.R.; SALEH, S.O.; ANDRADE, M. \& AKAMATSU, F. E. Relación inusual entre el músculo piriforme y los nervios isquiático, glúteo inferior y cutáneo femoral posterior. Int. J. Morphol., 32(2):432-434, 2014.

RESUMEN: El síndrome del músculo piriforme se ha reconocido cada vez más como una causa de dolor en las piernas. Tensión excesiva o variaciones anatómicas del nervio y del mús-
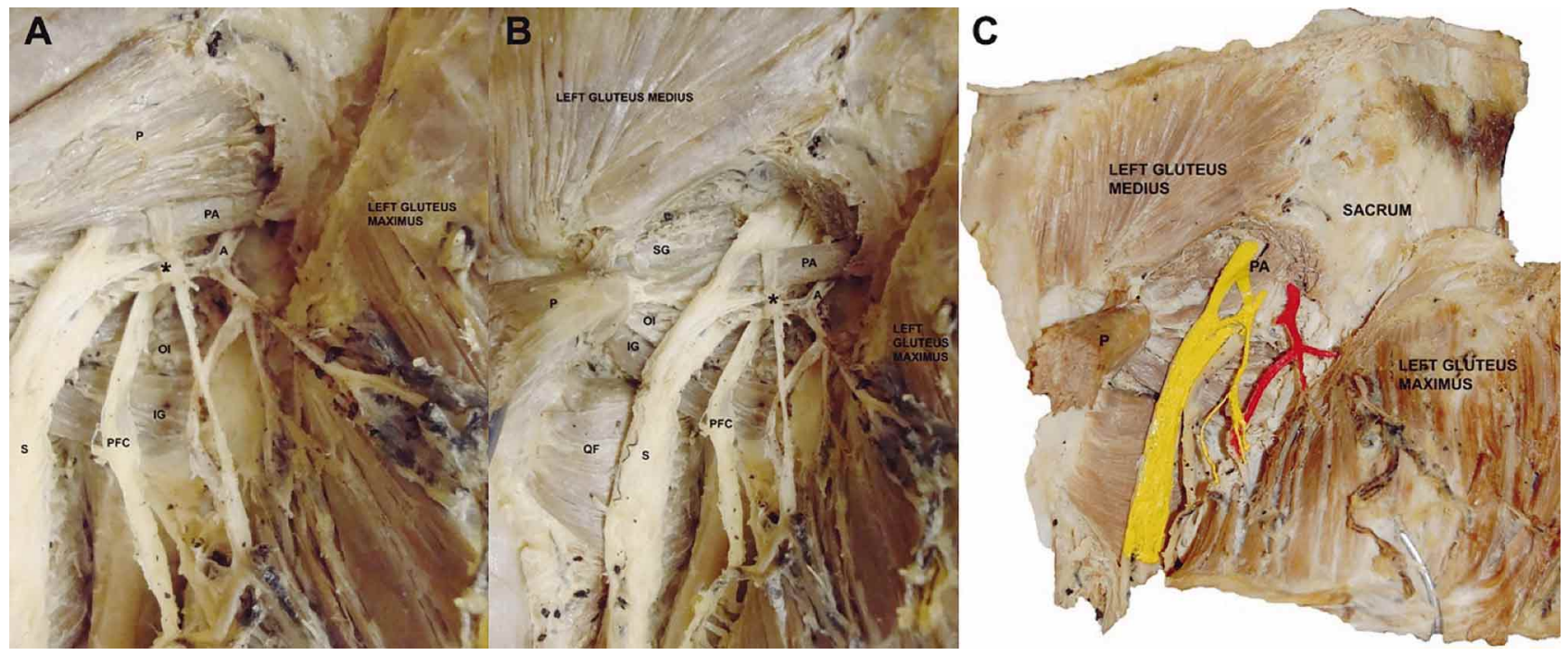

Fig. 1. Left gluteal region in A and B: piriform muscle (P); piriform accessory muscle (PA); artery (A); obturator internus muscle (OI); superior gemellus muscle (SG); inferior gemellus muscle (IG); posterior femoral cutaneous nerve (PFC); sciatic nerve (S); quadratus femoris muscle (QF). A. Piriform muscle is over piriform accessory; B. Piriform muscle was raised to observe the nerves disposition. Branches are highlighted by yellow ink in $\mathrm{C}$. 
culo piriforme se cree son las causas subyacentes de pinzamiento del nervio ciático. Se presenta una variación no descrita anteriormente. Durante una disección de rutina en un cadáver de sexo masculino, donde se observó una división más alta del nervio ciático y la presencia de un músculo piriforme accesorio. El nervio ciático se dividió bajo el músculo piriforme, y el nervio fibular común pasó sobre el músculo piriforme accesorio, mientras que el nervio tibial anterior se reflejó al pasar entre los músculos piriforme accesorio y gastrocnemio superior. Además, ambos nervios se comunicaban con un ramo lateral debajo del margen inferior del músculo piriforme accesorio del músculo y el nervio glúteo inferior se originó desde el nervio fibular. Variaciones anatómicas y relaciones entre el músculo piriforme y nervio ciático pueden estar presentes hasta el $17 \%$ de la población. Seis variaciones diferentes se han descrito y ninguna es similar a nuestra descripción. A pesar del compelto entendimiento de la fisiopatología del síndrome del músculo piramidal, aún queda por esclarecer y conocer las posibles variaciones anatómicas que pueden ser útiles tanto para su diagnóstico como para el tratamiento adecuado.

PALABRAS CLAVE: Nervio glúteo inferior; Nervio ciático; Músculo piriforme.

Beaton, L. E. \& Anson, B. J. The relation of the sciatic nerve and of its subdivisions to the piriformis muscle. Anat. Rec., 70(1):1$5,1937$.

Benzon, H. T.; Katz, J. A.; Benzon, H. A. \& Iqbal, M. S. Piriformis syndrome anatomic considerations, a new injection technique, and a review of the literature. Anesthesiology, 98(6):1442-8, 2003.

Cassidy, L.; Walters, A.; Bubb, K.; Shoja, M. M.; Tubbs, R. S. \& Loukas, M. Piriformis syndrome: implications of anatomical variations, diagnostic techniques, and treatment options. Surg. Radiol. Anat., 34(6):479-86, 2012.

Gabrielli, C.; Olave, E.; Mandiola, E. \& Rodrigues, C. F. S. Curso Nervo glúteo inferior associado a da divisão alta do nervo ciático. Rev. Chil. Anat., 15(1):79-83, 1997.

Güvencer, M.; Akyer, P.; Iyem, C.; Tetik, S. \& Naderi, S. Anatomic considerations and the relationship between the piriformis muscle and the sciatic nerve. Surg. Radiol. Anat., 30(6):46774, 2008.

Jawish, R. M.; Assoum, H. A. \& Khamis, C. F. Anatomical, clinical and electrical observations in piriformis syndrome. J. Orthop. Surg. Res., 5:3, 2010.

Mandiola, E.; Hernandez, H.; Hofer, U.; Crovetto, E. \& Ortega, E. Variaciones anatómicas del origen del nervio isquiático (en fetos humanos de término). An. Anat. Norm., 4(1):40-3, 1986.
Papadopoulos, E. C. \& Khan, S. N. Piriformis syndrome and low back pain: A new classification and review of the literature. Orthop. Clin. North Am., 35(1):65-71, 2004.

Smoll, N. R. Variations of the piriformis and sciatic nerve with clinical consequence: A Review. Clin. Anat., 23(1):8-17, 2010.

Correspondence to:

Flávia Emi Akamatsu

Rua Alexandre Dumas 1410, ap. 154

Chácara Santo Antonio

Santo Amaro, CEP:04717003

São Paulo, SP

BRAZIL

\author{
Email: flaea@usp.br \\ aljacomo@usp.br
}

Received: 17-12-2012

Accepted: 21-02-2014 